\title{
PENGARUH PROGRAM KEMITRAAN DAN KEBIJAKAN DEVIDEN TERHADAP KINERJA KEUANGAN PADA BANK BUMN
}

\author{
Khuzaeni ${ }^{1)}$ \\ 1) dosen universitas pamulang, email : dosen00558@unpam.ac.id
}

\section{ARTICLES}

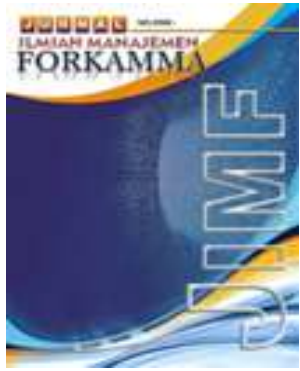

JURNAL ILMIAH MANAJEMEN FORKAMMA

Vol.2, No.1, November 2018 Halaman : 17-36

(c) LPPM \& FORKAMMA

Prodi Magister Manajemen

UNVERSITAS PAMULANG

ISSN (online) : 2599-171X

ISSN (print) : :2598-9545

Keyword :

service quality.culture

organization. customer

satisfaction

JEL. classification :

C33, G20, G23, N65

\section{Contact Author :}

\author{
PRODI \\ MAGISTER MANAJEMEN \& \\ FORKAMMA UNPAM \\ JL.Surya Kencana No.1 Pamulang \\ Tangerang Selatan - Banten \\ Telp. (021) 7412566, Fax (021) 7412491 \\ Email : \\ jurnalforkamma.unpam@gmail.com
}

Tujuan penelitian ini Salah satu barometer majumundurnya suatu perusahaan dapat diukur dari tingkat kinerja keuangan. Tingkat kinerja keuangan yang tinggi menggambarkan bahwa perusahaan tersebut efisiensi dalam penggunaan modal kerja sehingga akan diperoleh produktifitas. Pada akhirnya kinerja keuangan akan memberikan kebahagiaan bagi para pemegang saham terutama berkaitan dengan deviden yang akan diterimanya. Permasalahan yang muncul bagi manajemen adalah bagaimana kinerja keuangan yang dimanisfestasikan dengan laba yang diperoleh itu dikelola dengan baik. Pengelolaan laba tersebut terletak pada kebijakan deviden. Kebijakan deviden mengatur bagaimana laba yang diperoleh akan dialokasikan kepada para pemegang saham dalam bentuk deviden dan laba ditahan. Bagi BUMN permasalahan ini belum cukup karena ada kewajiban menyisihkan laba sebesar $1-5 \%$ bagi kegiatan Program Kemitraan dan Bina Lingkungan (PKBL). Hal ini kebijakan deviden alokasinya tidak hanya untuk pembayaran deviden dan laba ditahan saja melainkan ada tambahan untuk PKBL. Pada akhirnya penelitian ini ingin mengetahui seberapa besar pengaruh Program kemitraan dan kebijakan deviden terhadap kinerja keuangan pada bank BUMN. Data sekunder diambil dari laporan keuangan tahunan dari 3 sampel bank BUMN yang ada di Indonesia.. Analisis data menggunakan teknik analisa regresi parsial dan simultan. Hasil penelitian menemukan bahwa: Pertama, terdapat pengaruh antara Program Kemitraan dengan Kinerja Keuangan tidak kuat karena tingkat signifikan hanya sebesar $24,5 \%$. Kedua, tidak terdapat pengaruh antara Kebijakan deviden dengan Kinerja keuangan karena tingkat signifikannya sebesar 1,4\%. Ketiga, terdapat pengaruh antara Program Kemitraan dan Kebijakan deviden dengan Kinerja keuangan pada bank BUMN. 


\section{A. Pendahuluan}

Program kemitraan merupakan bentuk nyata tanggung jawab Perusahaan besar terhadap sosial maupun lingkungan (Corporate Social Responsibility). Ditengah masyarakat dunia yang semakin kritis dan peduli terhadap keberlangsungan lingkungan dalam jangka panjang dan menunjang nilai-nilai etika, CSR menjadi keharusan bagi suatu perusahaan besar. Pengertian CSR yang diambil dari buku Reputation-Driven Corporate Social Responsibility : "A Business acts in socially responsible manner when its decision and actions account for and balance diverse stakeholder interest". Definisi ini menekankan perlunya memberikan perhatian secara seimbang terhadap kepentingan berbagai stakeholder yang beragam dalam setiap keputusan dan tindakan yang diambil oleh para pelaku bisnis melalui perilaku secara sosial bertanggung jawab. Yang dimaksud stakeholder disini adalah para pemangku kepentingan yang dalam hal ini adalah orang atau kelompok yang dapat mempengaruhi atau dipengaruhi oleh berbagai keputusan, kebijakan, maupun operasi perusahaan. Ada 2 katagori pengklasifikasian stakeholders, yaitu :

1. Inside Stakeholders : Yaitu terdiri atas orang-orang yang memiliki kepentingan dan tuntutan terhadap sumber daya perusahaan serta berada di dalam organisasi perusahaan. Mereka yang disebut untuk ini adalah Pemegang Saham, para Manajer, dan karyawan (employees).

2. Outside Stakeholders : Yaitu terdiri atas orang-orang maupun pihak-pihak yang bukan pemilik perusahaan, bukan pemimpin perusahaan, dan bukan pula karyawan perusahaan, namun memiliki kepentingan terhadap perusahaan dan dipengaruhi oleh keputusan serta tindakan yang dilakukan oleh perusahaan. Mereka yang disebut Untuk ini adalah Pelanggan, Pemasok, Pemerintah, Masyarakat lokal, dan masyarakat secara umum.

Imbalan dan kontribusi masing-masing Stakeholders sebagai berikut :

\begin{tabular}{|l|l|ll|}
\hline Stakeholders & Kontribusi ke Perusahaan & Imbalan dari perusahaan \\
\hline Pemegang & Uang dan Modal & \multicolumn{2}{l|}{ Deviden dan peningkatan saham } \\
Saham & Kemampuan dan keahlian & Gaji, Bonus, promosi, dan \\
Para Manajer & Kemampuan dan keahlian & pekerjaan yang stabil \\
Para karyawan & Pembelian barang dan & Gaji, Bonus, promosi, dan \\
Pelanggan & jasa & pekerjaan yang stabil \\
Pemasok & Input berkualitas tinggi & Kualitas, harga barang dan jasa \\
Pemerintah & Penciptaan Peraturan & Pembelian input dengan harga \\
& & wajar \\
& & Memungut Pajak \\
\hline
\end{tabular}

Dikutip dari buku : Corporate Social Responsibility from Charity to Sustainability

Dari penjelasan diatas dapat dikatakan bahwa perusahaan dalam menjalankan tanggung jawab sosialnya memfokuskan perhatiannya tiga hal, yaitu Laba, Lingkungan, dan Masyarakat. Mengenai hal khusus fokus tanggung jawab kepada masyarakat dan lingkungan dapat dijalin sebuah Kemitraan yang akan saling melengkapi dan mutualisma. Perhatian terhadap masyarakat dalam menjalin sebuah kerja sama (Kemitraan) dapat dilakukan dengan cara melakukan aktivitas-aktivitas serta pembuatan kebijakan yang dapat meningkatkan kompetensi yang dimiliki diberbagai bidang. Kompetensi yang meningkat ini pada gilirannya diharapkan akan mampu dimanfaatkan bagi peningkatan kualitas hidup masyarakat.

Dengan menjalankan tanggung jawab sosial melalui program kemitraan ini, Maka perusahaan diharapkan tidak hanya mengejar keuntungan jangka pendek, namun juga turut berkontribusi bagi peningkatan kesejahteraan dan kualitas hidup masyarakat dan lingkungan sekitar dalam jangka panjang. 
Didalam pelaksanaan CSR yang dilakukan perusahaan besar masih mengundang pro dan kontra. Perusahaan yang memandang pelaksanaan CSR itu wajib dilaksanakan karena manajemen dalam perusahaan tidak hanya bertanggungjawab dalam perolehan laba saja demi kepentingan Pemegang Saham, akan tetapi mereka memiliki kewajiban untuk melindungi dan meningkatkan kesejahteraan masyarakat dalam arti luas. Eksistensi perusahaan bukan suatu entitas independen yang hanya bertanggung jawab kepada Pemegang Saham tanpa peran dari masyarakat. Masyarakat disini mempunyai peran yang besar terhadap eksistensi perusahaan itu sendiri terutama dalam pembelian produk barang atau jasa yang dihasilkannya, turut membentuk hukum dan undang-undang yang mengatur perilaku bisnis perusahaan, dan lain-lain. Menurut Ismail Solihin, pandangan perusahaan yang pro terhadap pelaksanaan CSR memliki alasan yang lebih luas lagi adalah sebagai berikut :

1. Ekspektasi Publik; Opini publik saat ini mendukung aktivitas bisnis yang mengejar tujuan-tujuan ekonomi dan juga berbagai sosial.

2. Laba jangka panjang; Perusahaan yang memiliki tanggung jawab sosial cenderung memiliki laba jangka panjang yang lebih aman.

3. Kewajiban etis; Pelaku bisnis harus memiliki tanggung jawab sosial karena tindakan-tindakan yang bertanggungjawab merupakan suatu hal yang benar untuk dilakukan.

4. Kesan Publik; Pelaku bisnis dapat menciptakan kesan publik yang baik bila mereka memiliki tujuan-tujuan sosial.

5. Menciptakan lingkungan yang lebih baik; Keterlibatan perusahaan besar dapat membantu pemecahan masalah-masalah sosial yang rumit.

6. Menyeimbangkan antara tanggung jawab dan kekuasaan; Perusahaan besar memiliki kekuasaan yang sangat besar sehingga tanggung jawab yang besar dalam jumlah yang sepadan perlu dimiliki oleh perusahaan sebagai penyeimbang atas kekuasaan yang sangat besar tersebut.

7. Kepentingan Pemegang Saham; Tanggung jawab sosial akan meningkatkan harga saham perusahaan dalam jangka panjang.

8. Kepemilikan terhadap sumber daya; Perusahaan korporasi memiliki sumber daya untuk mendukung proyek-proyek publik dan proyek amal yang membutuhkan bantuan perusahaan.

9. Mencegah lebih baik daripada mengobati; Para pelaku bisnis harus mewaspadai masalah sosial yang ditimbulkan dari operasi perusahaan sebelum praktik operasi perusahaan dikoreksi secara besar-besaran oleh publik yang dapat menimbulkan kerugian yang sangat besar bagi perusahaan.

10. Mencegah regulasi tambahan dari pemerintah; Dengan bertanggung jawab secara sosial pelaku bisnis dapat mengharapkan adanya regulasi dari pemerintah dalam jumlah yang lebih sedikit.

Sebaliknya terdapat beberapa perusahaan yang kontra terhadap pelaksanaan CSR. memandang bahwa manajemen sebagai agen dari pemegang saham mempunyai tugas utama, yaitu bagaimana seorang manajer bisa mengalokasikan sumber daya yang dimiliki perusahaan secara optimal dengan orientasi laba sebagai tujuan semata. Jika alokasi sumber daya akan mendatangkan rugi bagi perusahaan maka manajer dianggap bertentangan dengan kepentingan Pemegang Saham dan merupakan kegagalan manajer dalam mengelola perusahaan. Jadi dengan kata lain kegiatan CSR tidak akan memberikan manfaat bagi perusahaan melainkan hanya akan mendatangkan biaya besar (cost) yang pada akhirnya akan mengancam besaran laba perusahaan. Kritik lain dari pihak kontra CSR adalah kegiatan CSR yang dilakukan perusahaan pada kenyataannya hanya mengejar reputasi perusahaan di mata publik maupun pemerintah dan bukan untuk meningkatkan kesejahteraan masyarakat secara luas. Jadi kata kunci pihak kontra CSR dapat dikatakan sebagai berikut : 
1. Ketidakjelasan Tujuan; Mengejar tujuan sosial akan mengakibatkan ketidakjelasan pencapaian tujuan utama perusahaan yakni produktivitas secara ekonomi (Economic Produktivity).

2. Beban Biaya; Berbagai pelaksanaan program CSR merupakan beban biaya yang harus ditanggung perusahaan.

3. Perusahaan memiliki kekurangan keahlian dalam mengelola CSR; Pemimpin perusahaan pada umumnya memiliki keahlian yang kurang untuk menangani berbagai permasalahan sosial.

Ada beberapa penelitian sebelumnya terutama berkaitan dengan Kebijakan deviden dan Kinerja keuangan.

\section{Kebijakan Deviden}

Penelitian yang dilakukan D'souza et al. (1999) menunjukkan bukti bahwa perusahaan dengan tingkat risiko pasar yang semakin tinggi, membayar dividen semakin rendah. Semakin tinggi risiko yang harus ditanggung oleh perusahaan maka akan semakin sulit memperoleh dana eksternal sehingga perusahaan harus membiayai kebutuhan investasinya dengan menggunakan dana internal. Selanjutnya penelitian yang dilakukan oleh Ang et al. (1997) menjelaskan dalam hasil studi empirisnya tentang hubungan struktur modal dan kebijakan dividen pada perusahaan-perusahaan di Indonesia bahwa perusahaan-perusahaan di Indonesia memiliki akses yang baik terhadap berbagai sumber modal, khususnya bank dan equity market. Pinjaman bank jangka pendek dan menengah adalah yang paling disukai. Pendanaan dari pemasok dan sumber-sumber asing juga berperan penting. Meskipun laba ditahan (retained earnings) merupakan sumber yang lebih disukai, namun hal ini nampak tidak mencukupi. Tidak ditemukan bukti bahwa informasi asimetrik tentang bank dan equity market merupakan masalah yang signifikan. Perusahaan sangat mengharapkan melakukan penilaian secara fair dan menyediakan sumber daya yang cukup bagi perusahaan. Ditemukan bahwa perusahaan-perusahaan yang melakukan kebijakan dividen optimal dan berimbang mampu memiliki struktur modal yang lebih bagus. Penelitian ini menunjukkan bukti bahwa betapa besar harapan dan kebutuhan perusahaan-perusahaan di Indonesia terhadap modal dari pihak bank. Berikutnya Anand (2004), dalam penelitiannya, menemukan bahwa kebijakan dividen yang digunakan sebagai mekanisme yang menandai kondisi perusahaan saat sekarang dan prospek perusahaan pada masa yang akan datang, memiliki pengaruh terhadap nilai pasar dan pangsa pasar perusahaan. Tentu saja, kebijakan dividen dilakukan tidak terlepas dari pertimbangan-pertimbangan terhadap kesukaan investor (investors' preference) karena hal itu terkait dengan nilai pasar dan pangsa pasar perusahaan. Hasil penelitian ini mendukung sebuah teori yang menyatakan bahwa perusahaan didirikan dengan salah satu tujuannya adalah memaksimalkan kesejahteraan para pemilik saham. Prasetyo (2007) melakukan penelitian tentang hubungan simultan kepemilikan manajerial, risiko, kebijakan hutang, kebijakan dividen, dan kinerja keuangan perusahaan terbuka di Bursa Efek Jakarta.

Di antara temuan dalam penelitian ini adalah bahwa kebijakan hutang berhubungan negatif signifikan terhadap kebijakan dividen. Temuan lain adalah kebijakan hutang berpengaruh positif tidak signifikan terhadap risiko. Kebijakan hutang berhubungan positif signifikan terhadap kinerja keuangan perusahaan. Risiko berhubungan positif tidak signifikan dengan kebijakan dividen dan kebijakan dividen berhubungan positif signifikan dengan risiko. Kebijakan dividen berhubungan positif tidak signifikan dengan kinerja keuangan. 


\section{Kinerja Keuangan}

Penelitian yang dilakukan oleh Reynold et al. (2000) menguji hubungan langsung antara struktur modal dan kinerja bank. Rasio kinerja keuangan (seperti capital adequacy, liquidity, profitability, dan loan performance) dipengaruhi oleh beberapa variabel struktural (seperti aset bank, pendapatan bersih, biaya-biaya administrasi, dan waktu). Peneliti lain seperti Kunt dan Huizinga (2004) juga menguji hubungan antara struktur modal dengan kinerja keuangan bank. Bank-bank yang memiliki kinerja keuangan yang baik didukung oleh struktur permodalan yang optimal. Arsiraphongphisit dan Ariff (2003) menguji hubungan struktur modal dan nilai perusahaan. Ditemukan bahwa perusahaan-perusahaan yang memiliki struktur modal baik lebih mampu meningkatkan/menciptakan nilai. Perusahaan-perusahaan tersebut (highly-valued corporates) ditandai dengan kinerja yang berkualitas baik kinerja keuangan maupun kinerja non-keuangannya. Adapun studi hubungan langsung antara manajemen risiko dengan kinerja keuangan dilakukan oleh Cremonino dan Giorgino (2007). Ditemukan bahwa manajemen risiko sebagai aktivitas penciptaan nilai (value creation) berpengaruh siginifikan terhadap kinerja keuangan perusahaan.

\section{Analisis hubungan dengan Kemitraan}

Dari uraian di atas dapat disimpulkan bahwa variabel-variabel yang menjadi determinan kinerja perusahaan/perbankan berdasarkan hasil penelitian terdahulu di antaranya adalah manajemen risiko, kebijakan hutang, kebijakan dividen, dan struktur modal. Penelitian ini mencoba untuk menguji kembali pengaruh variabel manajemen risiko, kebijakan hutang, kebijakan dividen, dan struktur modal terhadap kinerja keuangan. Jika kita melihat penelitian yang dilakukan oleh Salvary (2004) menguji hubungan manajemen risiko dengan kebijakan dividen dan kinerja keuangan. Dimana pada penelitiannya didasarkan atas tujuan klasik perusahaan yang menyatakan bahwa perusahaan didirikan untuk memaksimalkan modal keuangan (financial capital) dan meminimalkan biaya-biaya. Tujuan tersebut bisa dicapai melalui aktivitas mengelola risiko karena itu berpengaruh terhadap aktivitas pembuatan keputusan dan kebijakan, termasuk kebijakan dividen dan pada gilirannya mempengaruhi struktur modal dan kinerja keuangan perusahaan. Ditemukan juga bahwa retensi laba perusahaan merupakan masalah organisasi di bawah ketidakpastian dan kebijakan dividen dipandang sebagai alat (instrument) manajemen risiko. Di depan sudah disebutkan bahwa Program kemitraan merupakan kewajiban bagi BUMN. Keputusan Menteri Keuangan Republik Indonesia Nomor 60/KMK.016/1996 menyebutkan tentang "Pedoman Pembinaan Usaha Kecil dan Koperasi melalui Pemanfaatan Dana dari bagian Laba BUMN", yang mewajibkan bahwa Badan Usaha Milik Negara (BUMN) menyisihkan dana pembinaan sebesar $1 \%-5 \%$ dari keuntungan bersih, sistem keterkaitan bapak Angkat Mitra Usaha, Penjualan saham perusahaan besar yang sehat kepada Koperasi dan lain sebagainya. Dampak yang nyata laba bersih BUMN semakin berkurang, diikuti kekayaan perusahaan berkurang karena ada dana yang harus dikeluarkan untuk program kemitraan.

Dengan demikian program kemitraan akan menjadi sebuah biaya (Cost) yang harus ditanggung BUMN sebagai salah satu tanggung jawab terhadap sosial dan lingkungan. Hal ini berarti ada keterkaitan dari penelitian Salvary (2004) yang menguji hubungan manajemen risiko dengan kebijakan dividen dan kinerja keuangan. Dimana pada penelitiannya didasarkan atas tujuan klasik perusahaan yang menyatakan bahwa perusahaan didirikan untuk memaksimalkan modal keuangan (financial capital) dan meminimalkan biaya-biaya. Jadi dalam pengertian lain Progran kemitraan mempunyai konsekuensi logis adanya ekstra biaya tambahan yang harus dikeluarkan perusahaan. Selanjutnya akan berpengaruh terhadap penetapan kebijakan deviden dan kinerja keuangan. 


\section{B. Perumusan Masalah}

Berdasarkan latar belakang yang telah diungkapkan di atas, maka rumusan masalah dalam penelitian ini adalah :

1. Apakah terdapat pengaruh Program kemitraan terhadap kinerja keuangan pada Bank BUMN?

2. Apakah terdapat pengaruh kebijakan deviden terhadap kinerja keuangan pada Bank BUMN?

3. Adakah terdapat pengaruh antara Program kemitraan dan Kebijakan deviden secara bersama-sama dengan Kinerja keuangan pada Bank BUMN ?

\section{Kerangka Berpikir}

\section{Program Kemitraan}

Kerjasama usaha antara usaha kecil dan usaha menengah dan atau besar dengan memperhatikan prinsip saling memerlukan, saling memperkuat, dan saling menguntungkan itulah yang disebut kemitraan. Kerjasama yang telah dilakukan secara berulang-ulang tersebut akan membentuk sebuah Program Kemitraan. Data Program kemitraan diambil dari jumlah dana yang dikeluarkan oleh Bank tersebut diperuntukan bagi Program Kemitraan dan Bina Lingkungan (PKBL).

\section{Kebijakan Deviden}

Kebijakan deviden merupakan kebijakan tentang berapa banyak bagian keuntungan yang dibagikan sebagai deviden (dividend payout) bagi pemegang saham dan sebagian lagi akan dialokasikan sebagai laba ditahan (earnings retained) yang akan dijadikan investasi bagi perusahaan yang akan datang. Untuk menghitung kebijakan deviden digunakan Devidend Payout Ratio (DPR) dengan rumus :

\section{Devidend Payout Ratio $($ DPR $)=\quad$ Deviden per saham \\ Laba bersih per saham}

\section{Kinerja Keuangan}

Data yang digunakan untuk mengukur kinerja keuangan adalah Laporan Keuangan. Laporan keuangan yang dimaksud dengan pendekatan Cash Flow, karena kinerja keuangan akan diukur lebih realistis dibanding dengan laporan rugi/laba (Income statement). Selanjutnya agar bisa dilihat kinerja keuangan, dalam penelitian ini diukur dengan menggunakan Cash Flow Return on Assets (CFROA) yang dihitung dengan rumus :

\section{CFROA = Laba sebelum bunga dan Pajak ditambah Depresiasi} Total Aktiva.

\section{Landasan Teori}

\section{Kemitraan}

Menurut kamus besar bahasa Indonesia kata kemitraan berasal dari kata dasar mitra yang berarti : teman, sahabat, kawan kerja, pasangan kerja, rekan. Setelah dapat tambahan kata usaha, maka kata mitrausaha bermakna: Partner dalam mengadakan usaha. Jika mendapat awalan, kata bermitra berarti: Menyatakan/mengakui sebagai mitra. Selanjutnya jika mendapat awalan dan akhiran (Konfik) kata kemitraan berarti: Perihal hubungan/jalinan kerja sama dan sebagainya/sebagai mitra. Menurut Peraturan Pemerintah Republik Indonesia Nomor 44 Tahun 1997 tentang kemitraan menyebutkan pengertian kemitraan adalah "Kerjasama usaha antara usaha kecil dan usaha menengah 
dan atau besar dengan memperhatikan prinsip saling memerlukan, saling memperkuat, dan saling menguntungkan". Dari definisi tersebut diatas dapat disimpulkan bahwa kemitraan dapat dijalin dengan melihat aspek simbiosis mutualisme dimana kedua pihak yang bermitra akan merasakan manfaatnya dan saling menguntungkan. Manfaat dari kemitraan ini salah satu diantaranya :

1. Faktor resiko bisnis dapat diperingan karena dapat ditanggung kedua belah pihak yang bermitra melalui risk sharing.

2. Faktor sosial ekonomi menjadi baik karena kemitraan dapat menekan kecemburuan sosial yang bisa berkembang menjadi kerawanan konflik di masyarakat.

3. Faktor ketahanan ekonomi nasional menjadi kuat dan tidak rapuh karena peran usaha besar, kecil, dan menengah saling mengisi dan melengkapi.

\section{BENTUK-BENTUK KEMITRAAN}

terdiri dari :

Menurut Undang-Undang NO.9 tahun 1995 tentang Usaha Kecil,bentuk kemitraan

\section{Kemitraan Inti-Plasma}

Kata inti menurut kamus besar Bahasa Indonesia berarti yang penting peranannya dalam suatu proses atau pelaksanaan kerja, sedangkan kata plasma berarti benih. Dengan demikian kemitraan inti-plasma dapat diartikan bentuk kemitraan dimana pihak pertama berperan dominan dalam proses/pelaksanaan kerja bermitra dengan pihak yang akan dijadikan plasma/benih yang akan memenuhi kebutuhan mitra intinya sesuai persyaratan yang telah disepakati. Peran dominan mitra inti dapat berupa penyediaan lahan, sarana produksi, bimbingan teknis, manajemen, menampung, mengolah, dan memasarkan hasil produksi dari mitra plasma.

\section{Kemitraan Sub-Kontrak}

Bentuk kemitraan ini merupakan pola hubungan kemitraan dimana mitra pertama memberikan lisensi/ijin kepada mitra kedua untuk dapat memproduksi bagian komponen produksi yang dibutuhkan oleh mitra pertama. Pemberian lisensi ini dengan membuat kontrak kerja bersama yang mencantumkan tentang volume, harga, dan waktu atas dasar kesepakan.

\section{Kemitraan Dagang Umum}

Bentuk kemitraan ini merupakan kerja sama dimana pihak mitra pertama bertindak sebagai pemasaran barang atau jasa sedangkan mitra kedua berusaha untuk menyuplai kebutuhan yang diperlukan untuk pemasarannya. Pola kemitraan ini pada dasarnya adalah hubungan membeli dan menjual terhadap produk yang dimitrakan. Dan kecenderungan pelaksanaannya dalam bentuk konsinyasi. Artinya barang-barang yang akan dijual merupakan barang-barang titipan dan jika tidak laku maka barang-barang tersebut akan dikirim kembali kepada mitra penyuplai.

\section{Kemitraan Keagenan}

Bentuk kemitraan ini merupakan salah satu bentuk hubungan kemitraan dimana mitra usaha pertama akan diberikan hak khusus untuk memasarkan barang dan jasa dari mitra usaha kedua. Hak khusus dalam memasarkan barang tersebut melalui pembukaan agen sebagai kepanjangan tangan dari Komiten. Keuntungan yang diperoleh dari hubungan kemitraan bentuk keagenan dapat berbentuk komisi atau fee yang diusahakan oleh pihak Komiten.

\section{Kemitraan Waralaba}

Bentuk kemitraan ini merupakan hubungan kerja sama usaha dimana pihak pemilik waralaba akan memberikan hak lisensi, merk dagang, saluran distribusi, dan disertai dengan bimbingan manajemen (sistem operasi, pelatihan, program pemasaran, dan lain-lain) sehingga pihak penerima waralaba ini melaksanakan kegiatan usaha hanya mengikuti pola yang sudah ditetapkan. Dengan demikian penerima waralaba ini akan memberikan kompensasi berupa royalti dan biaya lainnya yang terkait dengan kegiatan usaha tersebut. 


\section{KEMITRAAN DAN CORPORATE SOSIAL RESPONSIBILITY (CSR)}

Kemitraan terjadi karena adanya kerja sama yang saling menguntungkan kedua belah pihak. Kemitraan ini sangat dibutuhkan bagi UKM maupun Koperasi di dalam menjalankan roda kehidupan usaha. Keberadaan UKM di tengah-tengah kita akan menjamin adanya eksistensi ekonomi yang berbasis kerakyatan sehingga akan memelihara tegaknya sistem dan mekanisme pasar yang sehat dan berfungsinya aransemen kelembagaan atau regulasi pemerataan ekonomi yang efektif. Walaupun eksistensinya dibutuhkan UKM diakui masih belum bisa terlepas dari beberapa dari permasalahan klasik yang menyertainya. Masalah-masalah yang selalu menyertainya menurut Prof.Dr. Ina Primiana,S.E.,M.T adalah : Masalah seputar UKM di Indonesia adalah terletak pada permodalan, pemasaran, produksi / teknologi, sumber daya manusia, dan pemerintah. Masalah seputar UKM di Indonesia tersebut dapat dijabarkan lebih lanjut sebagai berikut :

\section{Permodalan}

a. Modal kecil, sulit Untuk memenuhi pesanan

b. Sulit mendapatkan kredit dsri bank. Sejak krisis moneter tahun 1998 bankbank di Indonesia sangat hati-hati memberikan kredit.

c. Kurang mampu mengadakan perencanaan, pencatatan, dan pelaporan. Tidak dapat membuat neraca dan laporan rugi/laba.

d. Tercampurnya antara keuangan perusahaan dengan keluarga.

\section{Pemasaran}
a. Kurang dapat melihat peluang pasar/selera pasar
b. Akses terhadap informasi pasar kurang
c. Terbatasnya tempat pemasaran
d. Kemampuan negosiasi yang lemah, sehingga berakibat kerugian pada sistem pembayaran dan perjanjian kontrak
e. Kurang kerjasama dengan perusahaan besar, sesama UKM, pihak luar negeri terutama dalam hal promosi
f. Kurang mampu merancang strategi bisnis.

\section{Produksi/Teknologi}
a. Kurangnya pengetahuan tentang bagaimana memproduksi barang yang berkualitas, efisien dan diserahkan tepat waktu
b. Tidak adanya transfer teknologi dari usaha besar
c. Tidak melakukan riset dan pengembangan
d. Tidak mengerti pentingnya kerjasama dengan pihak supplier
e. Tidak adanya proses perbaikan yang berkesinambungan (Continuous Improvement).

\section{Sumber daya Manusia}
a. Pendidikan rendah
b. Rendahnya jiwa wirausaha
c. Keahlian terbatas
d. Rendahnya produktivitas pekerja
e. Tidak ada pembagian kerja (job description).

\section{Pemerintah}

a. Kurangnya dukungan dengan berbagai kebijakan yang berpihak pada UKM

b. Kurangnya menciptakan lingkungan usaha yang kondusif. Pemerintah lebih mengutamakan pada perbaikan indikator makro, tetapi kurang mendorong kepada indikator mikro agar sektor riil UKM bergerak.

Dari permasalahan tersebut kedepan perlu adanya keberpihakan yang lebih serius terhadap UKM terutama dari Pemerintah.

Dengan potensi dan kelemahan-kelemahan yang ada pada UKM, maka diperlukan usaha-usaha agar UKM menjadi kuat dan mandiri. Solusi yang bisa ditawarkan dengan mengubah paradigma pada UKM. Perubahan paradigma baru sebagai pembinaan 
terhadap UKM yaitu : Pembinaan dengan pendekatan Dinamis (dynamic approach) dengan cara menciptakan atau membuat pasar baru yang ditujukan bagi UKM dan meningkatkan ketrampilan jiwa wirausaha.Untuk mewujudkan UKM agar menjadi kuat dan mandiri melalui pendekatan dinamis tersebut diatas, diantaranya :

1. Dukungan pemerintah antara lain dengan menggunakan perangkat dan sarana yang sudah ada, berupa jaringan Masyarakat Pos Ekonomi Rakyat (Jaringan PER) yang tersebar di pelosok-pelosok tanah air. Sehingga UKM akan mendapatkan akses informasi, baik informasi pasar, informasi perkreditan, informasi teknologi, dukungan konsultasi usaha yang relevan bagi UKM di daerah.

2. Jangan beri ikan, berilah pancingnya. Slogan tersebut yang perlu ditanamkan Untuk meningkatkan kewirausahaan UKM di Indonesia yang identik dengan profesionalisme dan kreativitas.

3. Pemberian kredit dapat dilakukan apabila tampak potensi UKM atau telah memiliki order. UKM menunjukkan kemajuan-kemajuan dalam kurun waktu tertentu dan faktor biaya merupakan kendala utama untuk memenuhi pesanan yang ditunjukkan oleh surat pesanan. Pembayaran kredit dilakukan setiap kali pesanan dilunasi. Begitu seterusnya Untuk order-order selanjutnya, artinya UKM dapat meminjam modal hanya Untuk membiayai pesanan pada saat tertentu.

4. UKM dianggap sebagai partner dengan prinsip win-win solution antara pemerintah/penjamin dan UKM.

5. Diperlukan pelatihan yang bertujuan Untuk merubah pola pikir sebagai seorang wirausaha agar UKM menjadi kuat. tidak manja, kreatif, inisiatif, dan produktif. Pelatihan-pelatihan tersebut bisa mengusung tema tentang perubahan paradigma usaha, pentingnya kepuasan pelanggan, meningkatkan kreativitas, inisiatif dan proaktif dalam usaha, dan lain-lain.

6. Memberdayakan peran pemerintah daerah Untuk meningkatkan UKM dengan melakukan langkah-langkah sebagai berikut :

a. Pilih UKM potensi masing-masing daerah

b. UKM terpilih membuat contoh/sampel produk yang dibuatnya (prototype)

c. Mencari kekurangan/kelebihan dari setiap prototype dengan bantuan tenaga ahli.

d. Mencari pasar untuk produk tersebut melalui pameran, internet, dan lain sebagainya.

e. Apabila ada pesanan dan sudah pasti jadi, maka UKM tersebut dapat dibantu oleh bank penjamin dengan dasar surat pesanan.

f. Diperlukan tenaga pendamping yang bertugas untuk mempersiapkan UKM siap mandiri, UKM berbasis kualitas,UKM siap melakukan perbaikan terus menerus.

Dengan beberapa fakta dan payung hukum yang telah dibuat bagi UKM, maka program kemitraan bagi Usaha kecil mendapat perlindungan Negara untuk dapat going concern dalam operasionalnya. Program kemitraan juga merupakan bentuk nyata tanggung jawab Perusahaan besar terhadap sosial maupun lingkungan (Corporate Social Responsibility). Ditengah masyarakat dunia yang semakin kritis dan peduli terhadap keberlangsungan lingkungan dalam jangka panjang dan menunjang nilai-nilai etika, CSR menjadi keharusan bagi suatu perusahaan besar. Pengertian CSR yang diambil dari buku Reputation-Driven Corporate Social Responsibility : "A Business acts in socially responsible manner when its decision and actions account for and balance diverse stakeholder interest". Definisi ini menekankan perlunya memberikan perhatian secara seimbang terhadap kepentingan berbagai stakeholder yang beragam dalam setiap keputusan dan tindakan yang diambil oleh para pelaku bisnis melalui perilaku secara sosial bertanggung jawab. 


\section{E. Metodologi Penelitian}

Penelitian dilakukan mengambil objek pada Bank BUMN dengan sampel yang telah dipilih yaitu : PT Bank Rakyat Indonesia,Tbk, PT Bank Mandiri,Tbk, dan PT Bank Mandiri,Tbk. Sampel ketiga Bank BUMN tersebut dipilih dengan alasan :

1. Bank tersebut telah konsisten menjalankan program kemitraan

2. Bank tersebut merupakan Bank BUMN yang memiliki brand image yang kuat

3. Bank tersebut dapat diakses secara lengkap dalam penelitian ini.

Sumber data yang digunakan dalam penelitian ini adalah Laporan keuangan yang telah diaudit Akuntan independen dari Bank Rakyat Indonesia, Bank Mandiri, dan Bank Bank Tabungan Negara selama 5 tahun berturut-turut dari tahun 2010 sampai dengan 2015. Laporan keuangan tersebut meliputi : Neraca, Laporan laba/rugi dan Laporan laba ditahan. Selanjutnya Datatersebut didapatkan dari Website bank bersangkutan dan tambahan dari Buku Institute for Economic and Financial Research Indonesian Capital Market Directory (ICMD).

Selanjutnya variabel bebas pada penelitian, yaitu Program kemitraan (Variabel $X_{1}$ ), Kebijakan devideni (Variabel $\mathrm{X}_{2}$ ) dan variabel terikatnya yaitu Kinerja keuangan (variabel $Y)$. Hubungan antara variabel bebas dengan variabel terikat tersebut disajikan pada model masalah berikut:

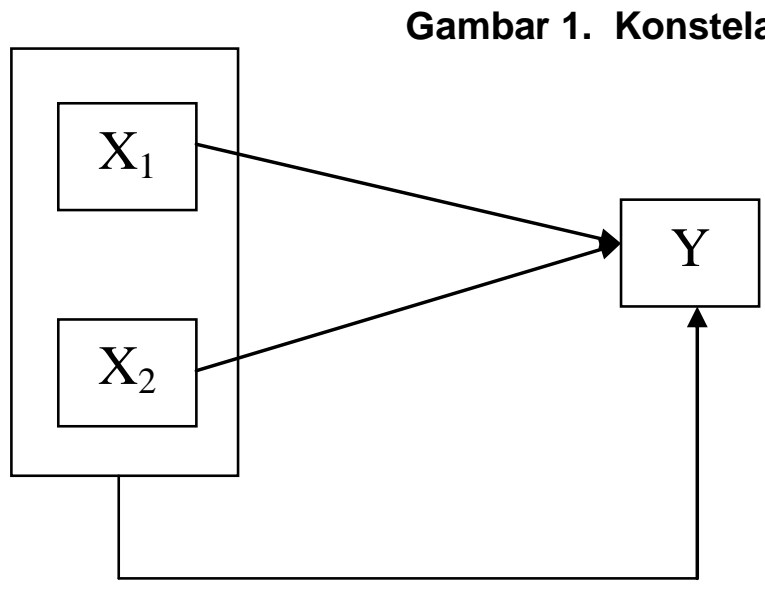

$Y=$ Variabel terikat : Kinerja keuangan

$\mathrm{X}_{1}=$ Variabel bebas $1:$ Program kemitraan

$\mathrm{X}_{2}=$ Variabel bebas $2:$ Kebijakan deviden

Analisis kuantitatif yang dipakai, sebagai berikut :

1. Analisa Regresi parsial dengan model :

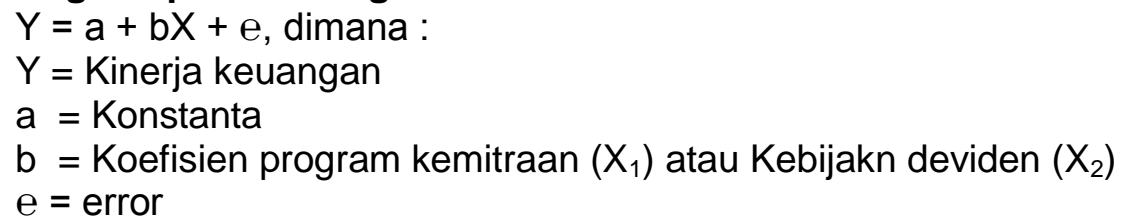

Model ini dilanjutkan Pengujian hipotesis untuk menentukan signifikan atau tidak untuk masing-masing nilai koefisien regresi variabel bebas (Prediktor) berupa Program kemitraan $\left(X_{1}\right)$ dan Kebijakan deviden $\left(X_{2}\right)$ secara sendiri-sendiri terhadap variabel terikat berupa Kinerja keuangan $(Y)$.

2. Analisa Regresi simultan dengan model :

$Y=a+b_{1} X_{1}+b_{2} X_{2}+e$, dimana:

$\mathrm{Y}=$ Kinerja keuangan.

$\mathrm{a}=$ Konstanta

$\mathrm{b}_{1}=$ Koefisien Program kemitraan $\left(\mathrm{X}_{1}\right)$ 


$$
\begin{aligned}
& \mathrm{b}_{2}=\text { Koefisien Kebijakn deviden }\left(\mathrm{X}_{2}\right) \\
& \mathrm{e}=\text { error }
\end{aligned}
$$

Model ini dilanjutkan Pengujian hipotesis yang melibatkan secara bersama kedua variabel bebas (Program kemitraan dan Kebijakan deviden) terhadap variabel terikat (Kinerja keuangan).

\section{Analisis Data}

Setelah data terkumpul maka dilakukan tahap analisis data, yaitu peneliti berusaha untuk memberikan uraian mengenai hasil penelitiannya. Dalam analisis data dilakukan beberapa tahapan yang meliputi: 1) Tahap Deskripsi Data dari laporan program kemitraan, Kebijakan deviden, dan kinerja keuangan dari laporan keuangan sampel bank BUMN yang dipilih. 2) Tahap Pengujian Hipotesis, Pengujian hipotesis pertama dan kedua masing-masing dilakukan dengan teknik regresi parsial, sedangkan hipotesis ketiga dengan regresi dan korelasi simultan.

\section{Uji Asumsi Klasik}

Pengujian ini dilakukan untuk melihat apakah data antar variabel bebas layak dipakai prediktor terhadap variabel terikat, diantaranya :

\section{Uji asumsi klasik Multikolinieritas}

Uji test ini berguna untuk menguji tingkat asosiasi (keeratan) pengaruh antar variabel bebas (Program kemitraan dan Kebijakan deviden) tersebut melalui besaran koefisien korelasi $(r)$, dengan besaran yang ditetapkan $r>0,60$ akan terjadi multikolinieritas. Sedangkan sebaliknya jika $r<0,60$ tidak terjadi multikolinieritas.

\section{Uji asumsi klasik Autokorelasi}

Uji ini untuk menguji data variabel bebas (Program kemitraan dan Kebijakan deviden) baik/tidak baik atau layak/tidak layak dipakai sebagai prediksi. Untuk menguji autokorelasi menggunakan uji Durbin-Watson (DW) dengan ketentuan :

- Terjadi autokorelasi positip jika nilai DW dibawah -2

- Tidak terjadi autokorelasi jika nilai DW berada diantara -2 dan +2

- Terjadi autokorelasi negatip jika nilai DW diatas +2

\section{Uji asumsi Heteroskedastisitas}

Uji ini berguna untuk menguji mengenai sama atau tidak varians dari residual dari observasi yang satu dengan observasi lain.

\section{Uji Normalitas}

Uji ini untuk menguji data variabel bebas (Program kemitraan dan Kebijakan deviden) serta variabel terikat (Kinerja keuangan) pada persamaan regresi yang dihasilkan, apakah berdistribusi normal atau tidak normal

\section{F. Hasil dan Pembahasan Penelitian Hasil Penelitian}

Berikut disajikan data yang diperoleh dari Sampel Bank BUMN berupa laporan keuangan tahunan selama 5 tahun berturut-turut dari tahun 2010 sampai dengan tahun 2015 yang telah diaudit oleh Akuntan Independent dari Bank Rakyat Indonesia (BRI), Bank mandiri, dan Bank Tabungan Negara (BTN).

\section{Program kemitraan Bank BUMN (X1)}


Deviden Payout Ratio

\begin{tabular}{|l|l|l|l|l|l|l|}
\hline \multicolumn{1}{|c|}{ Bank } & 2010 & 2011 & 2012 & 2013 & 2014 & 2015 \\
\hline BRI & 0,56 & 0,27 & 0,48 & 0,45 & 0,44 & 0,41 \\
\hline Mandiri & 0,52 & 0,51 & 0,50 & 0,12 & 0,33 & 1,86 \\
\hline BTN & 0,25 & 0,09 & 0,21 & 0,42 & 0,09 & 0,05 \\
\hline
\end{tabular}

\section{Kinerja Keuangan (Y)}

\begin{tabular}{|l|c|c|c|c|c|c|}
\hline \multicolumn{1}{|c|}{ Bank } & 2010 & 2011 & 2012 & 2013 & 2014 & 2015 \\
\hline BRI & 2,24 & 5,51 & 5,84 & 4,04 & 3,98 & 3,77 \\
\hline Mandiri & 3,01 & 3,23 & 0,68 & 1,27 & 2,17 & 2,39 \\
\hline BTN & 0,98 & 2,04 & 1,74 & 1,71 & 1,77 & 1,60 \\
\hline
\end{tabular}

Hasil analisis data yang tecantum pada tabel diatas dengan menggunakan alat analisa dengan SPSS adalah sebagai berikut :

Gambar 1.1 (Hasil regresi X1 terhadap Y)

\begin{tabular}{|l|r|r|r|r|r|}
\hline & \multicolumn{2}{|c|}{$\begin{array}{c}\text { Unstandardized } \\
\text { Coefficients }\end{array}$} & $\begin{array}{c}\text { Standardize } \\
d \\
\text { Coefficients }\end{array}$ & \multirow{2}{*}{ T } & \multirow{2}{*}{ Sig. } \\
\hline Model & B & Std. Error & Beta & & \\
\hline 1 (Constant) & 1.909 & .420 & & 4.545 & .000 \\
\hline x1 & $9.441 \mathrm{E}-12$ & .000 & .495 & 2.281 & .037 \\
\hline \multicolumn{7}{|l|}{ a Dependent Variable: $y$} \\
\hline
\end{tabular}

Dari out put data diatas, maka dapat dirumuskan persamaan regresi sebagai berikut :

$$
Y=1,909+9,441 X_{1}
$$

Analisa :

Konstanta sebesar 1,909 menyatakan bahwa jika tidak ada Program Kemitraan dan Bina Lingkungan (PKBL) yang dilakukan Bank BUMN, maka besarnya nilai Kinerja Keuangan diprediksikan sebesar 1,909. Sedangkan Koefisien $X_{1}$ sebesar 9,441 mengandung makna bahwa setiap penambahan Rp 1,00,- Program Kemitraan dan Bina Lingkungan (PKBL) maka akan dapat meningkatkan Kinerja Keuangan pada Bank BUMN sebesar 9,441.

\section{Gambar 1.2 ( Hasil R.Square X1 terhadap Y)}

Model Summary(b)

\begin{tabular}{|l|r|r|r|r|}
\hline Model & $\mathrm{R}$ & $\begin{array}{c}\mathrm{R} \\
\text { Square }\end{array}$ & $\begin{array}{c}\text { Adjusted R } \\
\text { Square }\end{array}$ & $\begin{array}{c}\text { Std. Error of the } \\
\text { Estimate }\end{array}$ \\
\hline 1 & $.495(\mathrm{a})$ & .245 & .198 & 1.21632 \\
\hline a Predictors: (Constant), x1 \\
\hline b Dependent Variable: $\mathrm{y}$
\end{tabular}


Analisa :

Nilai $R$ Square sebesar 0,245 maka menunjukkan bahwa besarnya pengaruh program kemitraan terhadap kinerja keuangan adalah sebesar 24,5\% sedangkan sisanya $75,5 \%$ dipengaruhi oleh faktor lainnya. Hal ini menunjukkan bahwa pengaruh program kemitraan terhadap kinerja keuangan tidak kuat atau lemah. Hal ini didasarkan pada besarnya nilai $R$ Square $<0,50$. Nilai standar error of estimate (SEE) sebesar 1,21632 menunjukkan bahwa besarnya kesalahan yang dapat terjadi atas kinerja keuangan dari adanya program kemitraan adalah sebesar 1,21632.

\section{Gambar 1.3 (Hasil uji t X1 terhadap Y)}

\begin{tabular}{|c|c|c|c|c|c|c|}
\hline \multicolumn{7}{|c|}{ Coefficients(a) } \\
\hline & & \multicolumn{2}{|c|}{$\begin{array}{c}\text { Unstandardized } \\
\text { Coefficients }\end{array}$} & \multirow{2}{*}{$\begin{array}{c}\text { Standardize } \\
\text { d } \\
\text { Coefficients }\end{array}$} & \multirow{2}{*}{$\mathrm{t}$} & \multirow{2}{*}{ Sig. } \\
\hline \multicolumn{2}{|c|}{ Model } & B & Std. Error & & & \\
\hline \multirow{2}{*}{1} & (Constant) & 1.909 & .420 & & 4.545 & .000 \\
\hline & $x 1$ & $9.441 \mathrm{E}-12$ & .000 & .495 & 2.281 & .037 \\
\hline \multicolumn{7}{|c|}{ a Dependent Variable: y } \\
\hline
\end{tabular}

\section{Analisa :}

Level of significance (a) sebesar $5 \%$ dengan banyak sampel $(n)=18$, maka nilai t tabel dapat ditentukan : ta/2; df $(n-2)=t 5 \% / 2 ; d f(18-2)=t$ 0,5\%; df $(16)=2,120$

Kriteria pengujian :

Ho akan ditolak jika t hitung $>\mathrm{t}$ tabel.

Ho akan diterima jika t hitung < t tabel.

Dari tabel olah data diatas maka dapat dilihat bahwa t hitung untuk variabel X1adalah sebesar 2,281 sedangkan nilai t tabel pada tingkat signifikansi 5\% diperoleh nilai 2,120. Dengan demikian dapat diambil kesimpulan bahwa t hitung $>$ dari $t$ tabel. Dari tabel diatas juga dapat dilihat bahwa tingkat signifikansi Untuk variabel $\mathrm{X}_{1}$ adalah sebesar 0,037 atau $3,7 \%$. Maka atas dasar nilai ini dapat disimpulkan juga bahwa pengaruh Program kemitraan tidak berpengaruh terhadap kinerja keuangan adalah signifikan karena nilai signifikansi atas nilai $t_{\text {hitung }}$, yaitu $(3,7 \%)<(5 \%)$.

Gambar 2.1 (Hasil regresi X2 terhadap Y)

\begin{tabular}{|c|c|c|c|c|c|}
\hline \multirow[b]{2}{*}{ Model } & \multicolumn{2}{|c|}{$\begin{array}{l}\text { Unstandardized } \\
\text { Coefficients }\end{array}$} & \multirow{2}{*}{$\begin{array}{c}\text { Standardize } \\
\text { d } \\
\text { Coefficients } \\
\text { Beta }\end{array}$} & \multirow{2}{*}{$\mathrm{T}$} & \multirow{2}{*}{ Sig. } \\
\hline & $B$ & Std. Error & & & \\
\hline \multirow{2}{*}{$1 \frac{\text { (Constant) }}{x 2}$} & 2.441 & .485 & & 5.034 & .000 \\
\hline & .401 & .851 & .117 & .471 & .644 \\
\hline \multicolumn{6}{|c|}{ a Dependent Variable: y } \\
\hline
\end{tabular}


Dari hasil diatas, maka dapat dirumuskan persamaan regresi sebagai berikut :

$$
\mathrm{Y}=2,441+0,401 \mathrm{X}_{2}
$$

Konstanta sebesar 2,441 menyatakan bahwa jika tidak ada kebijakan deviden yang dilakukan Bank BUMN, maka besarnya nilai Kinerja Keuangan diprediksikan sebesar 2,441 . Koefisien X2 sebesar 0,401 mengandung makna bahwa setiap penambahan satu satuan kebijakan deviden maka akan dapat meningkatkan Kinerja Keuangan pada Bank BUMN sebesar 2,441.

\section{Gambar 2.2 ( Hasil R.Square X2 terhadap Y)}

\begin{tabular}{|l|r|r|r|r|}
\hline \multicolumn{5}{|c|}{ Model Summary(b) } \\
\hline Model & $\mathrm{R}$ & $\mathrm{R}$ Square & $\begin{array}{c}\text { Adjusted R } \\
\text { Square }\end{array}$ & $\begin{array}{c}\text { Std. Error of the } \\
\text { Estimate }\end{array}$ \\
\hline 1 & $.117(\mathrm{a})$ & .014 & -.048 & 1.39058 \\
\hline a Predictors: (Constant), x2 & & & \\
\hline b Dependent Variable: $\mathrm{y}$ & & \\
\hline
\end{tabular}

Analisa :

Nilai $R$ Square sebesar 0,014 maka menunjukkan bahwa besarnya pengaruh kebijakan deviden terhadap kinerja keuangan adalah sebesar 1,4\% sedangkan sisanya 98,6\% dipengaruhi oleh faktor lainnya. Selain itu nilai $R$ square sebesar 0,014 juga menunjukkan bahwa kebijakan deviden tidak berpengaruh terhadap kinerja keuangan. Hal ini didasarkan pada besarnya nilai $R$ Square yang mendekati angka 0 . Nilai standar error of estimate (SEE) sebesar 1,39058 menunjukkan bahwa besarnya kesalahan yang dapat terjadi atas kinerja keuangan dari adanya kebijakan deviden adalah sebesar $1,39058$.

\section{Gambar 2.3 (Hasil uji t X2 terhadap Y)}

\begin{tabular}{|c|c|c|c|c|c|c|}
\hline \multicolumn{7}{|c|}{ Coefficients(a) } \\
\hline & & \multicolumn{2}{|c|}{$\begin{array}{l}\text { Unstandardized } \\
\text { Coefficients }\end{array}$} & \multirow{2}{*}{$\begin{array}{c}\begin{array}{c}\text { Standardize } \\
d \\
\text { Coefficients }\end{array} \\
\text { Beta }\end{array}$} & \multirow{2}{*}{$\mathrm{t}$} & \multirow{2}{*}{ Sig. } \\
\hline \multicolumn{2}{|c|}{ Model } & B & Std. Error & & & \\
\hline \multirow{2}{*}{1} & (Constant) & 2.441 & .485 & & 5.034 & .000 \\
\hline & $\mathrm{X} 2$ & .401 & .851 & .117 & .471 & .644 \\
\hline \multicolumn{7}{|c|}{ a Dependent Variable: y } \\
\hline
\end{tabular}

Analisa:

Level of significance (a) sebesar $5 \%$ dengan banyak sampel $(n)=18$, maka nilai t tabel dapat ditentukan : ta/2; df(n-2) =t 5\%/2;df(18-2) = t 0,5\%;df(16) $=2,120$

Kriteria pengujian :

Ho akan ditolak jika t hitung >t tabel.

Ho akan diterima jika t hitung $<\mathrm{t}$ tabel. 
Dari tabel olah data diatas maka dapat dilihat bahwa t hitung untuk variabel X2 adalah sebesar 0,471 sedangkan nilai t tabel pada tingkat signifikansi $5 \%$ diperoleh nilai 2,120. Dengan demikian dapat diambil kesimpulan bahwa $t$ hitung $<t$ tabel. Dan tingkat signifikansi untuk variabel X2 adalah sebesar 0,644 atau 6,44\%. Maka atas dasar nilai ini dapat disimpulkan juga bahwa pengaruh kebijakan deviden tidak berpengaruh terhadap Kinerja keuangan secara signifikan, karena nilai signifikansi atas nilai t hitung $(6,44 \%)$ lebih besar dari (5\%).

\section{Gambar 3.1 (R Squqre simultan, X1 dan X2 terhadap Y)}

\begin{tabular}{|l|r|r|r|r|r|}
\hline \multicolumn{7}{|c|}{ Model Summary(b) } \\
\hline Model & $\mathrm{R}$ & $\mathrm{R}$ Square & $\begin{array}{c}\text { Adjusted R } \\
\text { Square }\end{array}$ & $\begin{array}{c}\text { Std. Error of the } \\
\text { Estimate }\end{array}$ & Durbin-Watson \\
\hline 1 & $.533(\mathrm{a})$ & .284 & .189 & 1.22350 & 1.101 \\
\hline a Predictors: (Constant), x2, x1 & & & \\
\hline b Dependent Variable: $y$ & \\
\hline
\end{tabular}

Analisa :

Sumber : Hasil Olah Data

Nilai $\mathrm{R}$ Square sebesar 0,284 maka menunjukkan bahwa program kemitraan dan kebijakan deviden secara simultan berpengaruh terhadap kinerja keuangan adalah sebesar $28,4 \%$ sedangkan sisanya $71,6 \%$ dipengaruhi oleh faktor lainnya. Selain itu nilai $\mathrm{R}$ square sebesar 0,284 juga menunjukkan bahwa program kemitraan dan kebijakan deviden secara simultan memiliki pengaruh terhadap kinerja keuangan yang lemah atau tidak kuat. Hal ini didasarkan pada besarnya nilai $R$ Square yang $<0,50$. Nilai standar error of estimate (SEE) sebesar 1,22350 menunjukkan bahwa besarnya kesalahan yang dapat terjadi atas kinerja keuangan dari adanya program kemitraan dan kebijakan deviden adalah sebesar 1,22350.

\section{Gambar 3.2 (Persamaan regresi simultan X1 dan X2 terhadap Y)}

\section{Coefficients(a)}

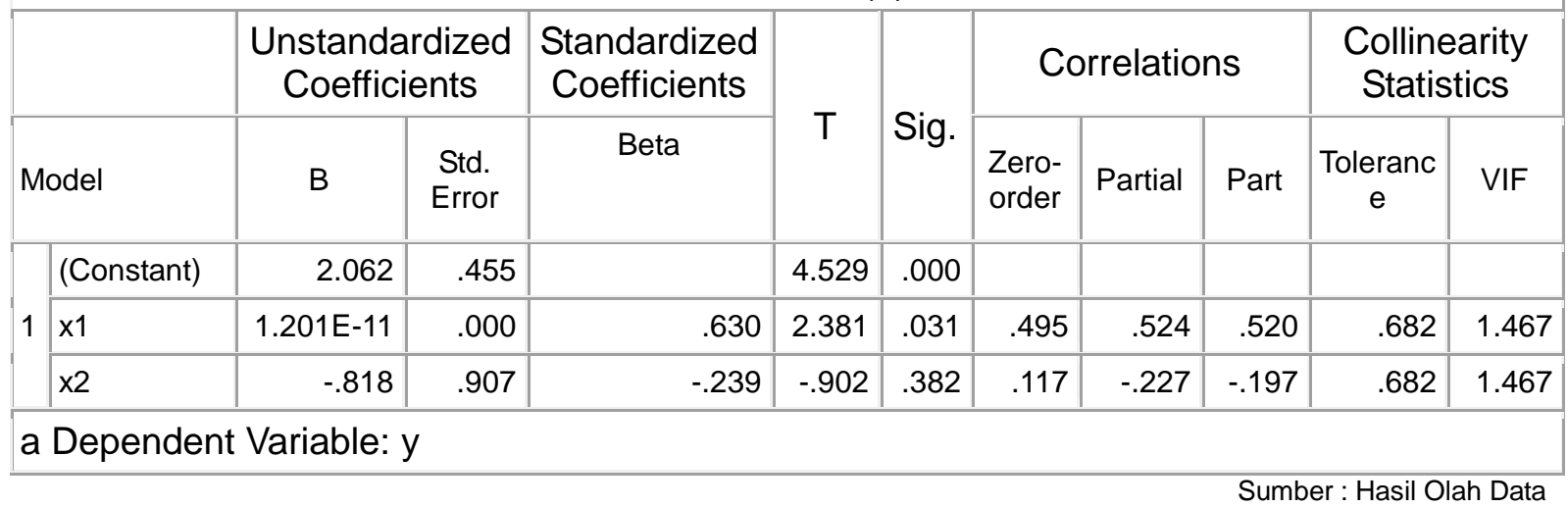

Analisa :

Konstanta sebesar 2,062 menunjukkan bahwa jika tidak ada program kemitraan dan kebijakan deviden, maka tingkat kinerja keuangan akan mencapai 2,062. Nilai 1,201X1 merupakan koefisien regresi yang menunjukkan bahwa setiap adanya upaya penambahan sebesar satu satuan biaya program kemitraan, maka ada kenaikan Kinerja keuangan sebesar 1,201 . Nilai $0,818 X 2$ merupakan koefisien regresi yang menunjukkan bahwa setiap adanya upaya penambahan sebesar satu satuan kebijakan deviden, maka akan ada penurunan kinerja keuangan sebesar 1,201. 
Gambar 3.3 ( Uji F, X1 dan X2 terhadap Y)

\begin{tabular}{|c|c|c|c|c|c|}
\hline \multicolumn{6}{|c|}{ ANOVA(b) } \\
\hline Model & Sum of Squares & $d f$ & $\begin{array}{l}\text { Mean } \\
\text { Square }\end{array}$ & $\mathrm{F}$ & Sig. \\
\hline Regression & 8.914 & 2 & 4.457 & 2.978 & $.081(\mathrm{a})$ \\
\hline 1 Residual & 22.454 & 15 & 1.497 & & \\
\hline Total & 31.368 & 17 & & & \\
\hline \multicolumn{6}{|c|}{ a Predictors: (Constant), x2, x1 } \\
\hline \multicolumn{6}{|c|}{ b Dependent Variable: y } \\
\hline
\end{tabular}

Analisa :

Level of significance (a) dengan uji $\mathrm{F}$ pada besaran (a) $5 \%$, df pembilang (numerator) $=3$, df penyebut (denominator) 15 , maka $\mathrm{F}$ tabel adalah sebesar 3,28

Kriteria pengujian :

Jika $\mathrm{F}$ hitung $>\mathrm{F}_{\text {tabel }}$ pada signifikansi $5 \%$, maka Ho: ditolak

Jika $F$ hitung $<F_{\text {tabel }}$ pada signifikansi $5 \%$, maka Ho: diterima

Kesimpulan dari hasil pengujian $F$ ini didapat besaran $F_{\text {hitung }}$ adalah 2,978. Sedangkan $F_{\text {tabel }}$ didapatkan besarannya adalah 3,28 (signifikansi 5\%). Dengan demikian Ho : diterima dan $\mathrm{Ha}$ : ditolak. Dapat diambil kesimpulan bahwa program kemitraan dan kebijakan deviden secara simultan tidak berpengaruh terhadap kinerja keuangan.

\section{Uji Asumsi Klasik}

Pengujian ini dilakukan untuk melihat apakah data antar variabel bebas layak dipakai prediktor terhadap variabel terikat, diantaranya :

\section{Uji asumsi klasik Multikolinieritas}

Uji test ini berguna untuk menguji tingkat asosiasi (keeratan) pengaruh antar variabel bebas (Program kemitraan dan Kebijakan deviden) tersebut melalui besaran koefisien korelasi ( $r$ ), dengan besaran yang ditetapkan $r>0,60$ akan terjadi multikolinieritas. Sedangkan sebaliknya jika $r<0,60$ tidak terjadi multikolinieritas. Hasil uji multikolinieritas terlihat dalam tabel dibawah ini :

\section{Gambar 4.1}

\begin{tabular}{|c|c|c|}
\hline \multicolumn{3}{|c|}{ Coefficients(a) } \\
\hline & \multicolumn{2}{|c|}{ Collinearity Statistics } \\
\hline Model & Tolerance & VIF \\
\hline KEMITRAAN & .682 & 1.467 \\
\hline KEBIJAKAN DEVIDEN & .682 & 1.467 \\
\hline
\end{tabular}


Coefficient Correlations(a)

\begin{tabular}{|c|c|c|c|c|}
\hline \multicolumn{3}{|c|}{ Model } & KEBIJAKAN DEVIDEN & KEMITRAAN \\
\hline \multirow{4}{*}{1} & \multirow{2}{*}{ Correlations } & KEBIJAKAN DEVIDEN & 1.000 & -.564 \\
\hline & & KEMITRAAN & -.564 & 1.000 \\
\hline & \multirow{2}{*}{ Covariances } & KEBIJAKAN DEVIDEN & .822 & $-2.581 E-12$ \\
\hline & & KEMITRAAN & $-2.581 E-12$ & $2.544 \mathrm{E}-23$ \\
\hline
\end{tabular}

Analisa :

Dari hasil olah data SPSS diatas, didapatkan besaran koefisien Collinearity Statistics adalah $-0,564$. Hal ini dapat disimpulkan bahwa keeratan pengaruh variabel bebas (program kemitraan dan kebijakan deviden) tidak terjadi multikolinieritas karena koefisien $r=-0,564<0,60$.

Alternatif penghitungan lain yaitu, Jika menggunakan besaran tolerance (a) dan variance inflation faktor (VIF). Jika menggunakan alpha/tolerance $=10 \%$ atau 0,10 maka VIF $=10$. Dari out put besar VIF hitung untuk Program kemitraan dan Kebijakan deviden sebesar $1,467<\mathrm{VIF}=10$, dan semua tolerance variabel bebas $(0,682=68,2 \%)$ diatas $10 \%$, dapat disimpulkan bahwa antar variabel bebas tersebut tidak terjadi multikolinieritas.

\section{Uji asumsi klasik Autokorelasi}

Uji ini untuk menguji data variabel bebas (Program kemitraan dan Kebijakan deviden) baik/tidak baik atau layak/tidak layak dipakai sebagai prediksi. Untuk menguji autokorelasi menggunakan uji Durbin-Watson (DW) dengan ketentuan :

- $\quad$ Terjadi autokorelasi positip jika nilai DW dibawah -2

- $\quad$ Tidak terjadi autokorelasi jika nilai DW berada diantara -2 dan +2

- $\quad$ Terjadi autokorelasi negatip jika nilai DW diatas +2

Hasil uji Autokorelasi dapat dilihat hasil olah data SPSS terlihat dalam tabel dibawah ini :

\section{Gambar 4.2}

Model Summary(b)

\begin{tabular}{|l|r|r|r|r|r|}
\hline Model & $\mathrm{R}$ & $\begin{array}{c}\mathrm{R} \\
\text { Square }\end{array}$ & $\begin{array}{c}\text { Adjusted R } \\
\text { Square }\end{array}$ & $\begin{array}{c}\text { Std. Error of } \\
\text { the Estimate }\end{array}$ & \multicolumn{1}{c|}{ Durbin-Watson } \\
\hline 1 & $.533(\mathrm{a})$ & .284 & .189 & 1.22350 & 1.101 \\
\hline \multicolumn{2}{l}{ a Predictors: (Constant), $\mathrm{x} 2, \mathrm{x} 1$} & \\
\hline
\end{tabular}

Analisa :

Dari hasil olah data SPSS diatas, didapatkan besaran koefisien Durbin-Watson adalah 1,101. Hal ini dapat disimpulkan bahwa variabel bebas (program kemitraan dan kebijakan deviden) layak dipakai sebagai prediksi terhadap kinerja keuangan, karena koefisien 1,101 dapat disimpulkan tidak terjadi autokorelasi karena ( $\mathrm{DW}=1,101$ berada diantara -2 dan +2$)$. 


\section{Uji asumsi Heteroskedastisitas}

Uji ini berguna untuk menguji mengenai sama atau tidak varians dari residual dari observasi yang satu dengan observasi lain. Hasil olah data SPSS terlihat dibawah ini :

\section{Gambar 4.3}

\section{Charts}

\section{Scatterplot}

\section{Dependent Variable: KINERJA KEUAN}

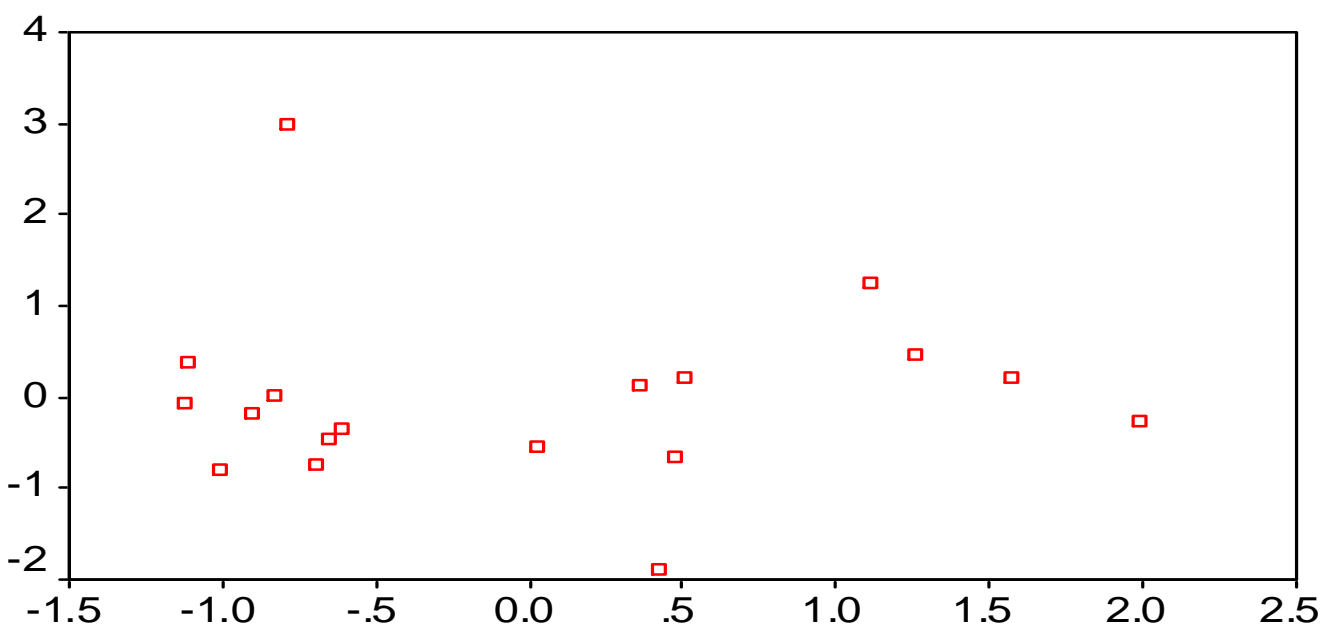

Regression Standardized Predicted Value

Sumber : Hasil Olah Data

Analisa :

Dari gambar grafik tersebut diatas dapat dilihat bahwa titik-titik yang terlihat tidak mempuntai pola yang teratur atau titik-titik tersebut menyebar ke segala arah yang tak teratur. Ini berarti data variabel bebas tidak terjadi heteroskedastisitas.

\section{Uji asumsi klasik Normalitas}

Uji ini untuk menguji data variabel bebas (Program kemitraan dan Kebijakan deviden) serta variabel terikat (Kinerja keuangan) pada persamaan regresi yang dihasilkan, apakah berdistribusi normal atau tidak normal. Hasil olah data SPSS terlihat dibawah ini : 
Gambar 4.4

\section{Charts}

\section{Histogram}

Dependent Variable: KINERJA KEUAN

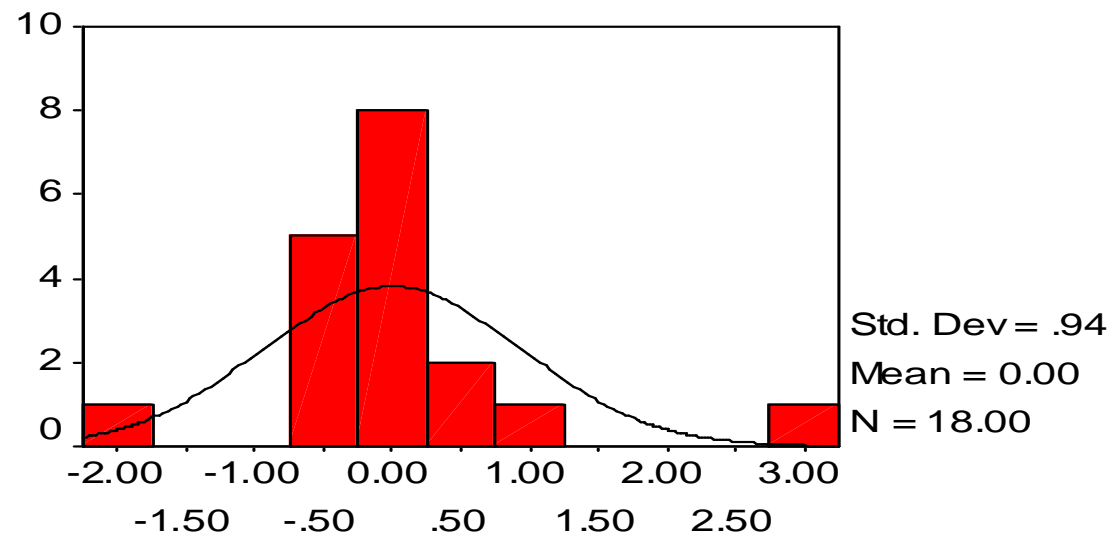

Regression Standardized Residual

Gambar 4.5

Normal P-P Plot of Regressio|

Dependent Variable: KINERJ

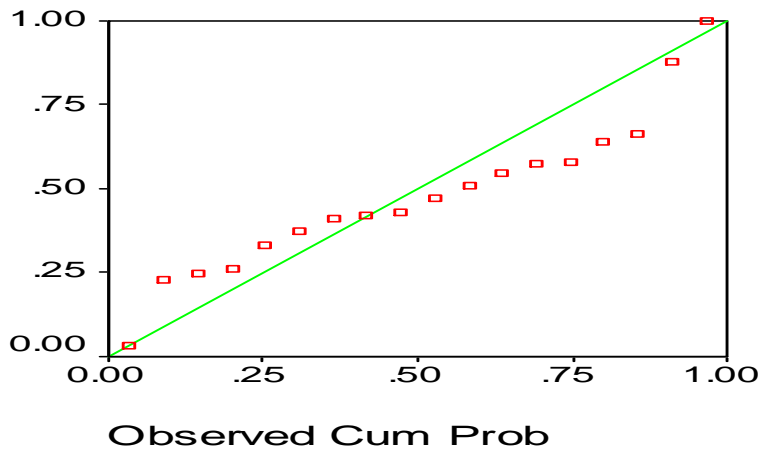

Analisa :

Dari hasil grafik histogram tersebut diatas terlihat garis kurva normal, berarti data yang diteliti pada variabel bebas (Program kemitraan dan Kebijakan deviden) berdistribusi normal. Demikian juga dari normal probability plots, menunjukkan berdistribusi normal karena garis (titik-titik) mengikuti garis normal. 


\section{G. Kesimpulan}

Setelah melalui serangkaian tahapan penelitian maka dapat diambil kesimpulan sebagai berikut :

1. Pengaruh program kemitraan terhadap kinerja keuangan padaBank BUMN tidak kuat karena tingkat koefisien hanya sebesar $24,5 \%$.

2. Pengaruh kebijakan deviden terhadap kinerja keuangan pada Bank BUMN tidak berpengaruh karena tidak koefisien sangat keci sebesar 1,4\%.

3. Secara simultan program kemitraan dan kebijakan deviden berpengaruh terhadap kinerja keuangan pada Bank BUMN tidak dapat disimpulkan, akan tetapi hanya sebatas sebagai prediksi saja.

\section{H. Daftar Pustaka}

1. A.B. Sutanto, 2009, Reputation-Driven Corporate Social Responsibility (Pendekatan Strategic Management dalam CSR), Erlangga, Jakarta.

2. Danang Suyoto, 2009, Analisis Regresi dan Uji Hipotesis, Med Press, Yogyakarta.

3. Handoyo Mardiyanto, 2009, Intisari Manajemen Keuangan (Teori, Soal, dan Jawaban), Grasindo, Jakarta.

4. Husein Umar, 2001, Riset Akuntansi (Dilengkapi dengan panduan membuat Skripsi, dan Empat bahasan kasus bidang Akuntansi, Grambedia Pustaka Utama, Jakarta.

5. Ina Primiana, 2009, Menggerakkan Sektor Riil UKM \& Industri, Alfabeta, Bandung.

6. Istitute For Economic and Financial Research Indonesia Capital Market Direcctory 2008.

7. Ismail Solihin, 2009, Corporate Social Responsibility (From Charity to Sustainability), Salemba Empat, Jakarta.

8. J. Supranto, 2004, Proposal Penelitian dengan Contoh, Universitas Indonesia, Jakarta.

9. Jurnal Akuntansi, 2008, Tahun XII/03/September, Fakultas Ekonomi Universitas Tarumanagara, Jakarta.

10. Lyn M. Fraiser dan Aileen Ormiston, 2008, Memahami Laporan Keuangan (Edisi Ketujuh), Indeks, Jakarta.

11. Mohammad Jafar, 1999, Kemitraan Usaha Konsepsi dan Strategi, Pustaka Sinar Harapan, Jakarta.

12. Mustafa Edwin Nasution dan Hardius Usman, 2007, Proses Penelitian Kuantitatif, Fakultas Ekonomi Universitas Indonesia, Jakarta.

13. Peter F.Druckter dan Udjian Wahyusuprapto, 1989, Mengelola Untuk Mencapai Hasil, Erlangga, Jakarta.

14. Sugiarto, 2009, Struktur Modal, Struktur Kepemilikan Perusahaan, Permasalahan Keagenan \& Informasi Asimetri, Graha IImu, Yogyakarta.

15. Syahri Alhusin, 2003, Aplikasi Statistik Praktis dengan SPSS.10 for Windows, Graha IImu, Yogyakarta.

16. Undang-Undang nomor 9 tahun 1995 tentang Usaha Kecil

17. Peraturan Pemerintah Republik Indonesia Nomor 44 tentang kemitraan

18. Keputusan Presiden Republik Indonesia nomor 99 tahun 1998

19. Keputusan Menteri Keuangan Republik Indonesia Nomor 60/KMK.016/1996

20. Undang-Undang nomor 40 tentang Perseroan Terbatas

21. Undang-Undang nomor 25 tahun 2007 tentang Penanaman Modal

22. www.bankbri.co.id

23. www.bankmandiri.co.id 